\title{
Tense and Modality in two creoles: Capeverdean and Saamáka
}

\author{
FERNANDA PRATAS ${ }^{\mathrm{a}}$ \& MARLEEN VAN DE VATE \\ ${ }^{\mathrm{a}}$ Centro de Linguística da Universidade de Lisboa
}

\section{$1 \quad$ Introduction}

In recent years, debates have revolved around the question whether epistemic modality can be in the scope of Tense. Some have argued that this is possible (see Eide 2003 for Norwegian, von Fintel \& Gilles 2008 for English, Martin to appear for French); while others have argued the opposite (see Condoravdi 2002 for English). The focus of this paper is the interaction of Tense and Modality in two creoles; Capeverdean (CV) ${ }^{1}$ and Saamáka $(\mathrm{SM})^{2}$. This paper provides evidence for the claim that in certain languages epistemic modality can have both a past and a present modal anchor time (in the case of CV), while in other languages epistemic modality must have a present modal anchor time (in the case of SM). Additionally, in his Language Bioprogram Hypothesis, Bickerton $(1981,1984)$ claims that tense, aspect and modality is similar across creoles. We will demonstrate that this claim is only partially correct. The modality system of these two creoles is very similar: Both have a necessity modal which conveys obligation and epistemic readings, and a possibility modal which conveys ability, permissive and epistemic readings. Furthermore, both have a past marker. A difference occur s when the past marker co-occurs with the modals; in $\mathrm{CV}$ both the circumstantial and epistemic reading of the two modals surfaces, whereas in SM only the circumstantial reading surfaces, the epistemic reading is infelicitous. The present paper accounts for this on the grounds of some important distinct features between these

\footnotetext{
${ }^{1}$ Capeverdean is a Portuguese-based creole, spoken by the half a million inhabitants of the Cape Verde Republic. This archipelago, to the west coast of Senegal, was a Portuguese colony until 1975. The substrate languages are mainly from the Mande and Atlantic families, spoken by the slaves from the Guinea Rivers area that were taken to Santiago Island in the $15^{\text {th }}$ century (Carreira 1982). The language is also the mother tongue of virtually all the estimated 1 million Capeverdeans in the diaspora (among others Portugal, The Netherlands, Switzerland, USA). Research for this work has been partly funded by FCT project Events and Subevents in Capeverdean (PTDC/CLE-LIN/103334/2008).

${ }^{2}$ Saamáka is an English/Portuguese-based creole spoken along the Suriname River, Suriname. The substrate languages are the Gbe languages and Kikongo (Smith 1987). The language was created by slaves who fled the plantations towards the end of the $17^{\text {th }}$ century (Price 1983). Currently, the language has 50.000 speakers (Aboh et al. to appear) who reside on the banks of the Suriname River, in Paramaribo, in French Guiana, and in The Netherlands. In the literature, the language is also referred to as Saramaccan.
} 
languages functional morphemes, which reflects in their respective functional structures. Evidence is provided that CV Past marker $-b a$ is a temporal affix (situated in TP), whereas SM Past marker $b i$ is a situational pronominal (situated in FinP). These facts bring a remarkable contribution to the debate around any possible default parameters regarding creoles. In other words, we assert that creoles do not necessarily behave alike (contra Bickerton).

The structure of the paper is as follows: Section 2 shows that CV and SM have some important similarities with respect to: (i) the necessity and possibility modals, and the way in which these may be interpreted; (ii) the temporal reading that circumstantial and epistemic modalities impose on the embedded eventualities, which depends on the aktionsart of these. Section 3 shows that there is a crucial distinction between the two languages: (i) in $\mathrm{CV}$, both in their epistemic and circumstantial readings, the modals may combine with the past marker - $b a$; (ii) in SM, when the modals combine with the past marker $b i$, only the circumstantial reading surfaces. Section 4 presents our proposal, on the grounds of some important distinct features between these languages' functional morphemes. Evidence is provided that CV Past marker $-b a$ is a temporal affix (situated in TP), whereas SM Past marker $b i$ is a situational pronominal (situated in FinP). In Section 5 we present some final remarks.

\section{Modals in Capeverdean and Saamáka: Some important similarities}

$\mathrm{CV}$ and SM have a necessity modal (debe and musu respectively) and a possibility modal (pode and $s a$ respectively) that are ambiguous between an epistemic and a circumstantial interpretation. This is illustrated for the necessity modals in (1) and (2) respectively ${ }^{3}$.

(1) Context: Today is not a holiday, and when two friends that meet for dinner wonder about whether another friend has worked or not, knowing their friend's habits, one of them says:

CV Djon debe trabadja.

SM Senni musu wooko.

$\mathrm{D} / \mathrm{S} \quad$ MOD work

'Djon/Senni must have worked.'

[epistemic]

\footnotetext{
${ }^{3}$ Abbreviations: $\mathrm{SG}=$ singular; $\mathrm{PL}=$ Plural; $\mathrm{MOD}=$ modal marker; $\mathrm{PST}=$ Past interpretation; $\mathrm{IMP}=$ Imperfective; $\mathrm{PROG}=$ Progressive $\mathrm{PF}=$ Perfect $\mathrm{NEG}=$ Negation; $\mathrm{BE}=$ Copula $; \mathrm{COMP}=$ Complementizer; $\mathrm{DET}=$ Determiner; $\mathrm{ART}=$ Article $; \mathrm{LOC}=$ Locative $; \mathrm{PREP}=$ Preposition; $\mathrm{Q}=$ Question marker; NARR $=$ narrative marker
} 
(2) Context: A father and a son are arguing, and the son says something that the mother, listening to the discussion, finds truly disrespectful; the mother says to the boy:

$\begin{array}{lllll}\text { CV } & B u & \text { debe rispeta bo pai. } \\ \text { SM } & Y u \text { musu lesipeki ditaatafii. } \\ & \text { 2SG MOD respect your father } \\ & \text { 'You must respect your father.' }\end{array}$

A second similarities is the temporal orientation of the modal evaluation time ${ }^{4}$ which correlates with the modal base and is aktionsart dependent. When epistemic modals embed a stative verb, the temporal orientation has a present interpretation, as illustrated in (3a) and (3b), whereas when they embed an eventive verb, the temporal orientation has a past interpretation, as illustrated in (3c) and (3d).
a. CV $E \quad k a$ debe sta dretu di kabesa.
3SG NEG MOD be well of head
'S/he must be out of his mind.'
b. SM A musu dé a wosu.
3SG MOD BE LOC house
'S/he must be at home'.
c: CV Djon debe txiga tardi onti noti Dja nen $N$
Djon MOD arrive late yesterday night already NEG $1 \mathrm{SG}$
ka obi-l ta entra.
NEG listen-3SG TA get.in

'Djon must have arrived late last night. I didn't even listen to him coming in.'

d. SM Jacky musu yasá beée tide bigá mi sumée feisi

$\mathrm{J}$ MOD bake bread today because $1 \mathrm{SG}$ smell fresh

beée dí mi pasá neen pisi.

bread when $1 \mathrm{SG}$ pass LOC.3SG place

'Jacky must have baked bread today, because when I passed her place I smelled fresh bread.'

When circumstantial modals embed a stative, the temporal orientation has a present/future reading, as illustrated in (4a) and (4b), while when they embed an eventive verb, the temporal orientation has a future interpretation, as illustrated in $(4 \mathrm{c})$ and $(4 \mathrm{~d})$.

\footnotetext{
${ }^{4}$ A clause containing a modal has two time intervals; a temporal perspective and a temporal orientation (see Condoravdi 2002, Laca 2008). The former refers to 'time from which the modal background is accessed' i.e. modal anchor time. Temporal orientation refers to 'the time at which the temporal property is instantiated' (Laca 2008:4) i.e. modal evaluation time.
} 
Fernanda Pratas \& Marleen van de Vate

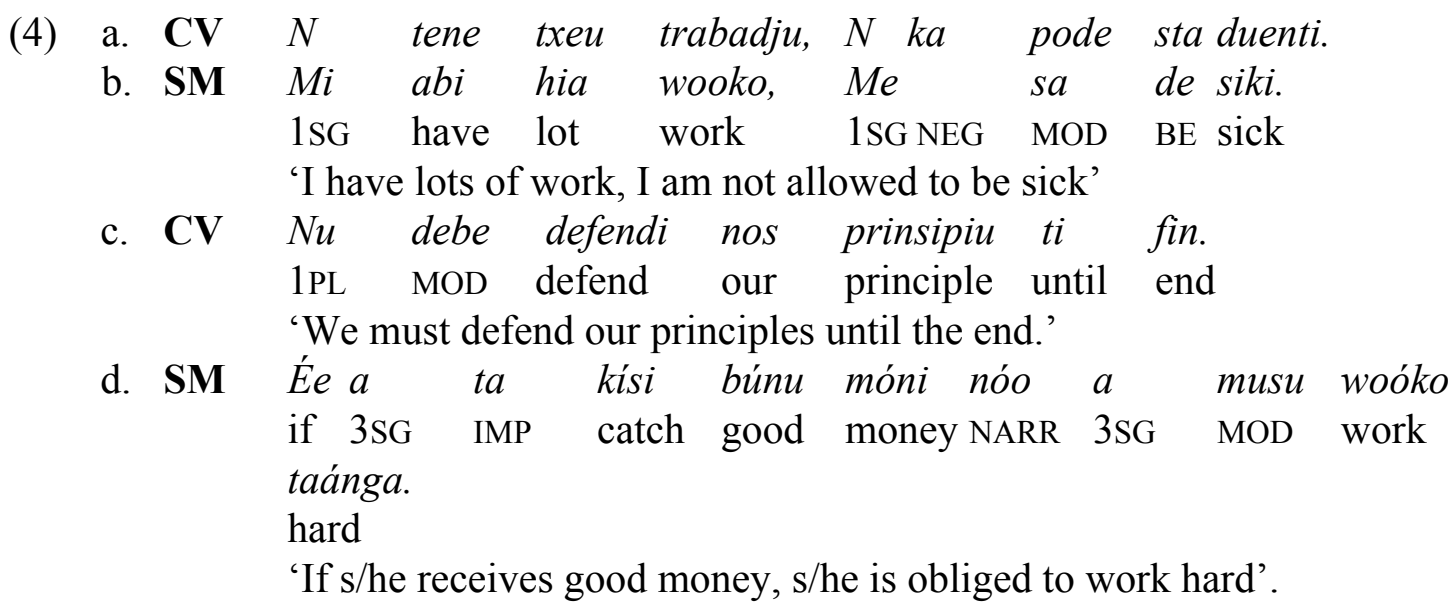

This difference in temporal orientation is due to the type of complement a modal embeds. Epistemic modals merge in a higher position (above TP) than circumstantial modals (above VP) (in the sense of Cinque 1999; Hacquard 2006). Consequently, epistemic modals embed Tense, while circumstantial modals do not embed Tense.

Additionally, we argue that both languages have a morphological null Perfect morpheme. This morpheme is obligatory in the underlying structure when the modal conveys an epistemic reading and embeds an eventide verb. In both languages Tense is momentary (i.e. expresses a moment) and is, therefore, restricted to embed a stative complement. Stative and eventive verbs are different in that the former are true at a moment, whereas eventive verbs need a subinterval of a moment to become true (in the sense of Taylor 1977, Bach 1981, Dowty 1979). Consequently in order to be able to combine with Tense, eventide verbs need to be modified by a state deriving functional head (this could be Perfect, Modals or some other operator, in the sense of Parsons 1990, Werner 2003). Epistemic modals embed a complement including Tense and Perfect. Perfect gives rise to the past interpretation. Since modals are also state deriving heads (Werner 2003), in their circumstantial reading, they also satisfy the stativity requirement placed by Tense on its complements. In these cases, the future interpretation is due to the modal itself (Condoravdi 2002, Werner 2003, Stowell 2004) $)^{5}$.

\section{Modals in the past: A crucial distinction}

In $\mathrm{CV}$, both in their epistemic and circumstantial readings, the modals may combine with the past marker $-b a^{6}$, as illustrated in (5)-(6) and (7) respectively.

(5) Context: A father discovers that the money his son brought home had been stolen from someone. Later, he told the police:

\footnotetext{
${ }^{5}$ We refer the interested reader to Pratas (2010) and van de Vate (2011) for discussion of the morphological null Perfect morpheme in CV and SM respectively.

${ }^{6} \mathrm{In} \mathrm{CV}$, the past epistemic reading is only possible with stative verbs.
} 
Tense and Modality in Capeverdean and Saamáka

Nunka ka pasa-m kabesa ma dinheru podeba never NEG get.through-1SG PREP head COMP money MOD:PST

ser furtadu.

be stolen

'It never occurred to me that the money might have been stolen.' [epistemic]

(6) Context: (from von Fintel \& Gillies 2008, example (21)) Pedru is looking for some ice cream and checks the freezer. There is none in there. Asked why he opened the freezer, he replies:

Pamodi podeba ten jeladu.

because MOD:PST have ice.cream

'Because there might be ice cream.'

[epistemic]

(7) Context: A student had a bad punctuation in an exam, and he strongly felt it was not fair. But he also knew that this was the kind of professor that you cannot argue with. Later, at dinner, he tells his mother:

$N \quad$ staba $k u$ raiba di pursor, mas $N$ ka podeba

$1 \mathrm{SG}$ be:PST with rage of professor but 1SG NEG MOD:PST

faze nada.

do nothing

'I was furious at the professor, but I couldn't do anything.' [circumstantial]

However, in SM, when the modals combine with the past marker bi, only the circumstantial reading surfaces, the epistemic reading is infelicitous, as illustrated in (8).
a. Senni bi musu go a Botopasi.
$\mathrm{S}$ PST MOD go LOC B
'Senni was obliged to go to Botopasi.'
*Senni must have gone to Botopasi.
$\begin{array}{ccllllll}\text { b. } & \text { Dí } & \text { wómi } & b i & \text { musu súti díngo } & \text { kíi. } \\ \text { DET } & \text { man } & \text { PST } & \text { MOD } & \text { shoot } & \text { DET } & \text { wild.pig } & \text { kill }\end{array}$
'The man had to kill the wild pig.'
(because it would have killed him otherwise)
*The man must have shot the wild pig.
[circumstantial]
[epistemic]
[circumstantial]
[epistemic]

In the next section we discuss the differences between the past markers in the two languages.

\section{The different positions of the past markers: $-b a$ in TP, $b i$ in FinP}

Before presenting our proposal, in Section 4.3, we describe some important differences between these languages' past morphemes. In Section 4.1, evidence is provided that CV 
Fernanda Pratas \& Marleen van de Vate

Past marker $-b a$ is a temporal affix (situated in TP). In Section 4.2, we argue that SM Past marker $b i$ is a situational pronominal (situated in FinP).

\subsection{The interpretation of Capeverdean -ba}

Evidence that $\mathrm{CV}$ past marker $-b a$ merges on $\mathrm{T}$ comes from two different lines of argumentation; (i) Its clear temporal contribution; (ii) The fact that it is a postverbal affix.

If $-b a$ were not a temporal morpheme, the following temporal contrast would be hard to explain.
a. $N$ sata odja tilivizon.
1SG PROG see television
'I'm watching tv.'
b. N sata odjaba tilivizon.
1SG PROG see.PST television
'I was watching tv.'

One could argue that this does not demonstrate anything about - $b a$ being in $\mathrm{T}$, since a past interpretation can also be the result of the morphological null Perfect morpheme (as well as of other operators). The null Perfect morpheme may occur in the absence of $-b a$, as illustrated in (10).

$$
\begin{aligned}
& \text { (10) } N \quad \varnothing \quad \text { odja tilivizon. } \\
& \text { 1SG PF see television } \\
& \text { 'I have watched tv.' }
\end{aligned}
$$

The temporal ordering relation expressed by $\mathrm{T}$ in (10) is distinct from the one in (9b). In (10), Topic Time overlaps the Time of Utterance, i.e., TT O TU (in the sense of Klein 1994). This gives a present interpretation. Since Present Tense can only embed a stative predicate (see Section 2), eventive verbs are obligatory modified by a state deriving functional head. In the absence of an overt operator, as in (10), the presence of the morphological null Perfect morpheme is triggered in the underlying structure. The past interpretation of the eventuality in (10) is due to the semantics of the Perfect, i.e. TT O TU; TSit $<$ TT. As a result, $e$ is situated prior to TU. However in (9b), $-b a$ sets Topic Time prior to Time of Utterance, i.e., TT $<$ TU. This results in a past interpretation. In other words, in (10) $\mathrm{T}$ expresses Present, while in (9b) $\mathrm{T}$ expresses Past. To complete the story, (9a) contains the progressive morpheme sata. The temporal ordering relation in $\mathrm{T}$ gives rise to a present interpretation, i.e., TT O TU, while the temporal ordering relation under Aspect gives rise to a imperfective reading, i.e., TSit O TT (in the sense of Klein 1994). Please note that progressive is also a state deriving functional head (in the sense of Parsons 1990).

The sentence in (11) demonstrates that the morphological null Perfect and - $b a$ can cooccur. This gives rise to a past-before-past interpretation (or Past Perfect), i.e., TT < TU; 
TSit $<$ TT.
(11) $N$
ø odjaba tilivizon.
1SG PF see.PST television
'I had watched tv.'

The second line of argumentation in favor of $-b a$ situated in $\mathrm{T}$ is that, when a verb is marked by $-b a$, the object clitic is forbidden and we must have a free pronominal form, as illustrated in (12).
(12) a. Nodja.
'I saw'.
b. Nodja-l.
'I saw him/her'.
c. N ta odjaba.
'I used to see'.
d. *N ta odjaba-l
e. N ta odjaba el.
'I used to see him/her'?

This shows that $-b a$ affixes to the verb before the object clitic. This postverbal affixed position is the result of lowering of - $b a$ to the verb (Pratas 2007, see also Bobaljik's (1995) proposal for -ed in English).

\subsection{The interpretation of Saamáka $b i$}

The morpheme bi conveys a simple past reading, as exemplified in (13) and (14) and a past-before-past reading, as exemplified in (15) and (16). These readings are not influenced by Aktionsart.

(13) Context: A girl was late for school this morning and therefore she had to run to be on time.

A bi kulé gó a
3SG PSTrun go LOC
'She ran to school'.

\footnotetext{
${ }^{7}$ Pratas \& Salanova (2005) have explained the above restriction on the object clitics in the following way: the stress of CV words always fall on the penultimate mora; in a. we have 'ódja', which is ok; in c. the temporal affix changes the stress of the word, and we get 'odjába' - this is ok, since the stress still falls on the verb root; then, we have another phonological fact in the language, which is: the final clitic counts as moraic in the phonological word that it forms with the verb; so, it also changes the stress of the word; in b. 'odjá-l', this is ok, since the stress still falls on the verb root; the problems come when we have both the affix and the clitic for the phonological rule to apply, we would have the stress on the affix (* 'odjabá-l'), and this is bad. So, in this case we must have a free pronominal, which a different word and, thus, does not interfere with the stress of the verb + affix.
} 
(14) Lathoya bi suáki ma a béte. L PSTill but $3 \mathrm{SG}$ better 'Lathoya was ill, but she is better now'.

(15) Dí mi doú éside ndéti a wósu nóo mi sísa when $1 \mathrm{SG}$ arrive yesterday night LOC house NARR $1 \mathrm{SG}$ sister bi skifi tú biifi kabá kaa PSTwrite two letter finish already 'When I arrived home yesterday evening, my sister had written two letters already'.

(16) Éside Senni bi ta woóko.Dí wiki dí bi pasá de yesterday $\mathrm{S}$ PST IMP work DET week DET PSTpass there a bi suáki. 3SG PST ill

'Yesterday Senni was working. The week before, he had been ill'.

Interestingly, it is possible to omit the morpheme $b i$ in a narrative context ${ }^{8}$.

(17) Context: In May 2006, the Suriname River was flooded due to the rain fall in Brazil. Several villages along the Suriname river were flooded by water. Houses and vegetable gardens were destroyed.
a. Yoó dá u to?
3SG.MOD give 1PLright
F: 'You will give us something, right?'
b. Únfa dí gaánwáta bigí u kó únfa $i \quad$ dú. how DET flood start FU come how $2 \mathrm{SG}$ do F: 'When the flood started to come, what did you do?'
c. Mé bi dé akí.
1SG.NEG PST BE here
S: 'I was not here.'
d. Ohyá bi dé aki?
oh 2SG.NEG PST BE here
F: 'Oh, you were not here?'
e. Mi dé a Semoisi.
1SG BE LOC S
S: 'I was in Semoisi.'
f. Ohyá bi dé aki nó?
oh 2SG.NEG PST BE here RQ
M: 'Oh, you were not here?'

\footnotetext{
${ }^{8}$ Abbreviations: $\mathrm{F}=$ Fonteni, guide and interpreter; $\mathrm{S}=$ Sina, an elderly monolingual woman and main narrator; $\mathrm{M}=$ Marleen. Please note that the Saamáka of the author is that of a second language learner. This interview was recorded in March 2009 in Pikin Slee, Suriname
} 


\section{Tense and Modality in Capeverdean and Saamáka}

g. Nóno mi dé a Semoisi. Di a kó a dóu té. no 1SG BE LOC $\mathrm{S}$ when 3SG come 3SG arrive until S: 'No, I was in Semoisi. When it came, it reached up to there. .......'

This extract demonstrates that from line (17b), the whole conversation is temporally located at the time of the flood in 2006 i.e. $e<$ TU. Additionally, stative verbs, which have a present interpretation when they are unmarked and require $b i$ to express a past interpretation, can be not marked by $b i$ and still convey a past time reference reading, as illustrated for the copula dé in (17e) and (17g). From this we conclude that the presence of $b i$ is discourse sensitive, i.e., its occurrence depends on certain features of the discourse context.

The omission of $b i$ in SM is also demonstrated in clausal structures. In (18) and (19) two events take place which are both marked with the imperfective morpheme $t a$. In both examples, the eventualities are interpreted as occurring simultaneously and are located prior to Time of Utterance.
(18) $a$
a. Senni bi ta bebe te hen Lathoya ta nya beée. $S$ PST IMP drink tea NARR L IMP eat bread 'Senni was drinking tea and Lathoya was eating bread'.
b. $\mathrm{e} 1 \circ \mathrm{e} 2<\mathrm{TU}$
(19) a. Di muyee ta naai kosu nóo a bi ta konda wan DET womanIMP sew cloth NARR $3 \mathrm{SG}$ PST IMP tell ART sondi a dee sembe. thing LOC DET.PL person 'The woman was sewing cloth(s) while she was telling something to the others'. b. e1 $\circ$ e $2<\mathrm{TU}$

Another characteristic of $b i$ is that anchoring of a narrative can only occur when a storyline is not interrupted by a different storyline, as demonstrated in $(20)^{9}$.

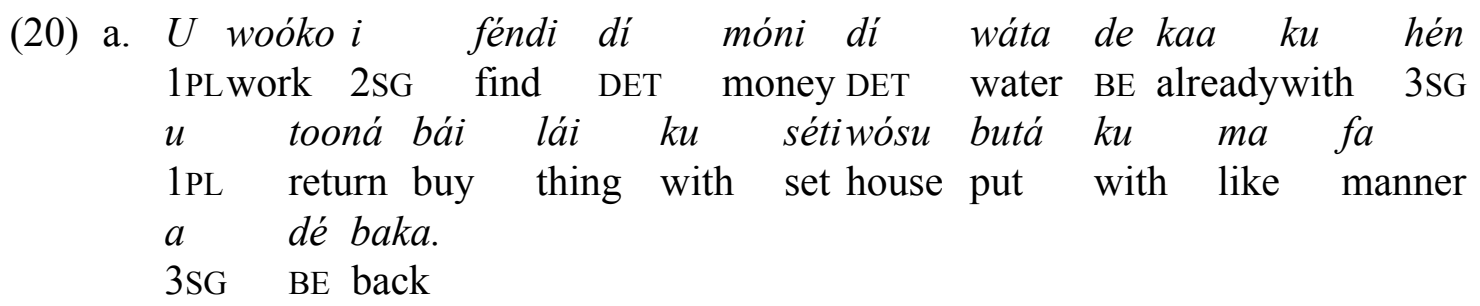

\footnotetext{
${ }^{9}$ The following abbreviations are relevant for this extract. $\mathrm{L}=$ Laurens, guide and interpreter; $\mathrm{Y}=$ Yeye, an elderly monolingual woman and main narrator. President Venitiaan was at that moment of the flood in 2006 the president of the Republic of Suriname, and still was when this conversation was recorded in March 2008. Vinije is Yeye's grandson who lives in Wageningen, The Netherlands. After the flood in 2006, he visited his family in Pikin Slee.
} 
L: 'We worked and found money, the water went down. With the money, we bought things again and decorated our houses again'.

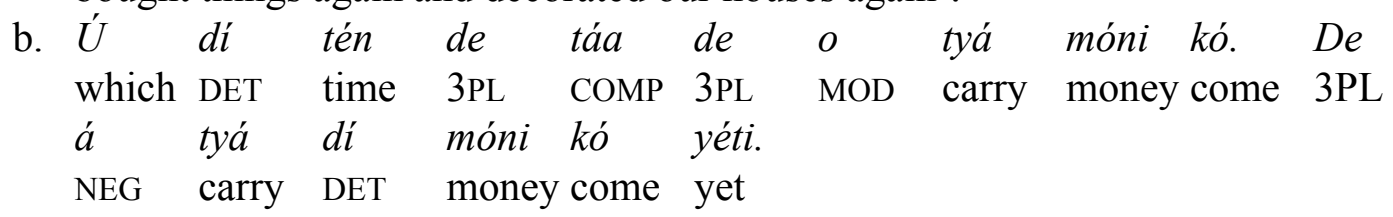

Y: 'In those days, they said that they would bring money. They have not brought the money yet'.

Line (a) and (b) refer to storyline $\mathrm{A} \rightarrow$ Flood 2006

c. .............

d. Kumafá dí u Botopasi de. Fá a dé a Botopasi de like DET FU B there like 3SG BE LOC B there nóo $u$ Seei akí musu ábi tú. NARR FU $\mathrm{P}$ here MOD have also

L: 'Like the one in Botopasi. Like it is in Botopasi, we of Pikin Slee must have one too'.

Line (c) and (d) refer to storyline B

e. Dí Venitiaan bi kó akí a di a bi dú dá when $\mathrm{V}$ PST come here LOC when 3SG PST do give u a Seei aki a di lío déndu.

1PL LOC $\mathrm{P}$ here LOC DET river in(side)

L: 'Venitiaan came here and he gave help to us in Pikin Slee'.

f. $\dot{A}$ heépi ná wán wee sondí. Vinije kó a dí

3SG.NEG help NEG ART at.all thing $\mathrm{V}$ come LOC DET

kónde ta daamá ta butá sondí a di kónde ta

village IMP walk around IMP place thing LOC DET village IMP

lóntu

round

$\mathrm{Y}$ : 'He helped us with nothing. Vinije came to the village en was walking around in the village'.

Line (e) and (f) refer to storyline $\mathrm{A} \rightarrow$ Flood 2006

This extract demonstrates that when a new temporal past discourse topic is introduced, the first predicate(s) is marked by $b i$. Secondly, when a sequence of eventualities is interrupted by a different storyline, the anchor time of the first storyline has to be re-established when the speaker continues with the first storyline. Thirdly, an anchor time must locally bind its antecedent(s)

To summarize, the morpheme $b i$ has the following characteristics. The morpheme conveys a past time reference reading and it anchors an eventuality to some past time which is inconsistent with past from a future perspective. The eventuality embedded by $b i$ is not necessarily anchored to Time of Utterance. The morpheme is insensitive to aktionsart. Finally, $b i$ is discourse sensitive; the presence of $b i$ is sometimes omitted 


\section{Tense and Modality in Capeverdean and Saamáka}

To explain these characteristics of $b i$, we argue that $b i$ is a discourse marker which has the role of a temporal pronominal (in the sense of Partee 1984, Kratzer 1998). We postulate that $b i$ establishes the Anchor Time directly and that all eventualities are anchored to this Anchor Time. Moreover, $b i$ is restricted to establish an Anchor Time prior to Time of Utterance. We argue that $b i$ is located in Fin in the syntactic structure (in the sense of Enç $1987)^{10}$.

\subsection{A past epistemic reading}

\subsubsection{The felicity of a past epistemic interpretation in |Capeverdean}

The following two lines of assumptions may seem incompatible. First, epistemic modals merge in a higher position (above TP) than circumstantial modals (above vP) (in the sense of Cinque 1999; Hacquard 2006). Consequently, epistemic modals embed T, while circumstantial modals do not embed T. Second, $-b a$ is situated in T. Under these two assumptions, it might seem difficult to explain why in $\mathrm{CV}$ the epistemic reading is felicitous, as illustrated in (21) which is repeated below.

\section{(21) Dinheru podeba serfurtadu. money MOD:PST be stolen}

'The money might have been stolen.'

[epistemic]

This is the crucial distinction between CV and SM that we are trying to account for. The question that needs to be answered is: How can this reversed order with regards to the semantic interpretation be explained, i.e., modification of epistemic modality by $\mathrm{T}$. Interestingly, these type of sentences do not occur in out-of-the-blue contexts; they must be either inserted in a context that already has past interpretation, or embedded under a past clause. Stative verbs are modified by $-b a$, while eventive verbs are modified by the morphological null Perfect morpheme, as illustrated in (22a) and (22b) respectively.
a. Si pai staba prokupadu pamodi dinheru podeba serfurtadu. his father be:PST worry because money MOD:PST be stolen 'His father was worried because the money might have been stolen.' [epistemic]
b. Pulisia fla ma dinheru podeba serfurtadu. police say COMP money MOD:PST be stolen 'The policeman said that the money might have been stolen.' [epistemic]

We argue that tense marking on the embedded epistemic modal is not a real tense. It is not relevant to anchoring the embedded clause in time (in the sense of Iatridou 1990). If this is

\footnotetext{
${ }^{10}$ For a detailed discussion of the semantic and syntactic characteristics of $b i$, we refer the interested reader to van de Vate (2011).
} 
Fernanda Pratas \& Marleen van de Vate

on the right track, we have the set of predictions below.

(i) matrix past + embedded past epistemic modal ok see (22)

(ii) matrix present + embedded past epistemic modal odd see (23)

(iii) matrix past + embedded past circumstantial modal ok see (24)

(iv) matrix present + embedded past circumstantial modal ok see (25)

(23) ??Pulisia sata fla ma dinheru podeba serfurtadu. police PROG say COMP money MOD:PST be stolen

'The policeman is saying that the money might have been stolen.' [epistemic]

(24) a. Si pai staba prokupadu pamodidinheru podeba furtada. his father be:PST worried because money MOD:PST be.stolen 'His father was worried because the money could have been stolen.'

[circumstantial]

b. Pulisia fla ma dinheru podeba furtada. police say COMP money MOD:PST be.stolen

'The policeman said that the money could have been stolen.' [circumstantial]

(25) a. Djon sta prokupadu pamodi Pedru debeba trabadja ti tardi.

Djon be worried because Pedru MOD:PST work until late

'Djon is worried because Pedru was obliged to work until late.'[circumstantial]

b. Djon sata fla ma Pedru debeba trabadja ti tardi.

Djon PROG say COMP Pedru MOD:PST work until late

'Djon is saying that Pedru was obliged to work until late.' [circumstantial]

The fact that epistemic modals marked for past can only embed eventualities either with stative verbs or with an eventive marked by the progressive, as in (26), is crucial for this hypothesis. These types of statives are the ones that necessarily have a temporal reading simultaneous to the matrix past.

(26) Maria ka faze raboliso pamodi. E podeba sata durmi. Maria NEG make noise because 3SG MOD:PST PROG sleep Maria didn't make any noise because he might be sleeping.'

The prohibition of the Perfect, which also gives a past interpretation of the eventuality, is accounted for by arguing that it would bring a shifted reading, which, in CV, is forbidden in these contexts.

\subsubsection{The infelicity of a past epistemic interpretation in Saamáka}

Given the syntactic structure (i.e. $b i$ being situated in FinP), it would be expected that the combination of $b i$ and a modal morpheme would also give rise to a past epistemic 
interpretation. However, as (27) illustrate, which is repeated here, this reading is infelicitous.

(27) Dí wómi bi musu súti di píngo kíi.

DET man PST MOD shoot DET wild.pig kill

'The man had to kill the wild pig.'

(because it would have killed him otherwise)

*'The man must have shot the wild pig'.

[circumstantial]

[epistemic]

To account for this, we argue that modals in their epistemic reading cannot combine with $b i$ because they are obligatorily anchored to Time of Utterance (in the sense of Hacquard 2006). Since bi establishes an Anchor Time prior to Time of Utterance, there is a mismatch regarding the temporal interpretation between $b i$ and the epistemic modals. This temporal mismatch results in the infelicity of an epistemic reading with a past modal anchor time in SM (van de Vate 2011).

\section{$5 \quad$ Conclusion}

This paper discussed the interaction of tense and modality in Capeverdean and in Saamáka. It was shown that the modal system in these languages is very similar. Both have a necessity and possibility modal which can convey a circumstantial and an epistemic interpretation. The interpretation of the modal base correlates with temporal orientation and Aktionsart. In the circumstantial reading, the modal evaluation time has a future orientation. In the epistemic reading the temporal orientation is Aktionsart dependent: Stative verbs give rise to a present orientation of the modal evaluation time, while eventive verbs give rise to a past orientation. We argued that the future orientation of circumstantial modals is due to the modal itself, while the past orientation of epistemic modals is due to the presence of the morphological null Perfect morpheme in the underlying structure of the clause. The languages differ with regard to the semantic and syntactic characteristics of their past markers. It was shown that $\mathrm{CV}$ has a Past Tense marker, - $b a$, which is situated in TP, while $\mathrm{SM}$ has a situational pronominal which establishes a past Anchor Time, $b i$, which is situated in FinP. Another difference is the possible readings that surface when modals combine with these past markers. In CV both the circumstantial and epistemic interpretation is available (for stative verbs, not for eventive verbs), while in SM only the circumstantial reading is available. Whether these differences are due to influence of the substrate languages (Mande for $\mathrm{CV}$, and Gbe and Kikongo for SM) is left for future research.

\section{References}

Aboh, Enoch, Norval Smith and Tonjes Veenstra. to appear. Saramaccan. In M. Haspelmath, M. Huber, P. Maurer, and S. Michaelis, eds., .Atlas of Pidgin and Creole 
Fernanda Pratas \& Marleen van de Vate

language structures. Oxford: Oxford University Press.

Bach, Emmon. 1981. On Time, Tense, and Aspect: An Essay in English Metaphysics. In P. Cole, ed., Radical Pragmatics, 63-81, New York: Academic Press.

Bickerton, Derek. 1981. Roots of Language. Karoma Publishers.

Bickerton, Derek. 1984. The Language Bioprogram Hypothesis. The Behavioral and Brain Sciences 7:173-188.

Bobaljik, Jonathan. 1995. Morphosyntax: The Syntax of Verbal Inflection. PhD thesis, MIT.

Carreira, António. 1982. O Crioulo de Cabo Verde, Surto e Expansão. Mem Martins: Europam.

Cinque, Guglielmo. 1999. Adverbs and functional heads. Oxford: Oxford University Press.

Condoravdi, Cleo. 2002. Temporal interpretation of modals: Modals for the present and for the past. In D. Beaver, S. Kaufmann, B. Clark, and L. Casillas, eds., The construction of meaning, 59-88, Stanford, CA: CSLI.

Dowty, David. 1979. Meaning and Montague Grammar. Dordrecht: Reidel.

Eide, Kristin M. 2003. Modals and Tense. In M. Weisgerber, ed., Proceedings of Sinn und Bedeutung 7, 120-135, Konstanz Arbeitspapier Nb. 114, FB Sprachwissenschaft.

Enç Mürvet. 1987. Anchoring conditions for tense. Linguistic Inquiry 18:633-657.

von Fintel, Kai \& Anthony S. Gillies. 2008. CIA leaks. The Philosophical Review 117:7798.

Hacquard, Valentine. 2006. Aspects of Modality. PhD thesis, MIT.

Iatridou, Sabine. 1990. The Past, the Possible and the Evident. Linguistic Inquiry 21:123-29.

Klein, Wolfgang. 1994. Time in Language. Routledge, London.

Kratzer, Angelika. 1998. More structural analogies between pronouns and tenses. In D. Strolovitch and A. Lawson, eds., Proceedings of SALT VIII, Ithaca: CLC Publications.

Laca, Brenda. 2008. On modal tenses and tensed modals. Ms., Université Paris 8. 


\section{Tense and Modality in Capeverdean and Saamáka}

Martin, Fabienne. to appear. Epistemic modals in the past. In J. Berns, H. Jacobs and T. Scheer, eds., Proceedings of Going Romance 2009.

Parsons, Terry. 1990. Events in the semantics of English: A study in subatomic semantics. Cambridge, Mass.: MIT Press.

Partee, Barbara. 1984. Nominal and temporal anaphora. Linguistics and Philosophy 7:243286

Pratas, Fernanda. 2007. Tense features and argument structure in Capeverdean predicates. $\mathrm{PhD}$ thesis, UNL.

Pratas, Fernanda. 2010. States and Temporal Interpretation in Capeverdean. In, R. BokBennema, B. Kampers-Manhe and Bart Hollebrandse, eds., Romance Languages and Linguistic Theory 2008. Selected papers from Going Romance Groningen 2008, 215-231, Amsterdam: John Benjamins.

Pratas, Fernanda \& Andrés Salanova. 2005. The allomorphy of Capeverdean object pronominals: A case for late insertion. Paper presented at the 15è Colloqui de Gramàtica Generativa. Universitat de Barcelona.

Price, Richard 1983 First-time: The historical vision of an African American people. Baltimore: John Hopkins University Press.

Smith, Norval 1987 The genesis of the creole languages of Suriname. PhD thesis, University of Amsterdam.

Stowell, Tim. 2004. Tense and modals. In J. Guéron and J. Lecarme, eds., The syntax of time, 621-635, Cambridge, Mass.: MIT Press.

Taylor, Barry. 1977. Tense and continuity. Linguistics and Philosophy 1:199-220.

van de Vate, Marleen. 2011. Tense, Aspect and Modality in a radical creole: The case of Saamáka. PhD thesis, University of Tromsø.

Werner, Tom. 2003. Deducing the future and distinguishing the past: temporal interpretation in modal sentences in English. $\mathrm{PhD}$ thesis, Rutgers. 
Fernanda Pratas \& Marleen van de Vate

\author{
Fernanda Pratas \\ Complexo Interdisciplinar da Universidade de Lisboa \\ Av. Prof. Gama Pinto, 2 \\ 1649-003 Lisboa - Portugal \\ fcpratas@gmail.pt \\ Marleen van de Vate \\ m.s.vandevate@gmail.com
}

